This PDF is a selection from a published volume from the National Bureau of Economic Research

Volume Title: NBER International Seminar on Macroeconomics 2008

Volume Author/Editor: Jeffrey Frankel and Christopher Pissarides, organizers

Volume Publisher: University of Chicago Press

Volume ISBN: 978-0-226-10732-5

ISSN: 1932-8796

Volume URL: http://www.nber.org/books/fran08-1

Conference Date: June 20-21, 2008

Publication Date: April 2009

Chapter Title: Reflections on Monetary Policy in the Open Economy

Chapter Author: Richard H. Clarida

Chapter URL: http://www.nber.org/chapters/c8235

Chapter pages in book: (p. 121 - 141) 


\section{Reflections on Monetary Policy in the Open Economy}

Richard H. Clarida, Columbia University and NBER

\section{Introduction}

A perennial topic of discussion among scholars and policy makers is how best to think about a benchmark for macroeconomics as it applies to monetary policy. Should the benchmark for policy analysis be the open economy with international interest rate linkages and flexible exchange rates (after all, major economies are in fact open with flexible exchange rates), or should it be the closed economy in which such linkages and exchange rate adjustments are assumed away? Of course, few if any policy makers would seek to guide policy by ignoring capital flows and exchange rates, but in many cases it appears as though the starting point for analysis is the closed-economy macro model, these days a variant of the dynamic new Keynesian model.

Those who start from a closed-economy framework often have questions about how "openness" influences the analysis. How does the neutral real interest depend on "global" developments? Is the Phillips curve trade-off between inflation and domestic output better or worse in the open versus the closed economy? Is "potential GDP" a function of global developments, or only of domestic resources available and domestic productivity? Perhaps most important, how—if at all—does openness influence the optimal monetary policy rule? Is a Taylor rule the right monetary policy for an open economy?

In 2002 Jordi Gali, Mark Gertler, and I published a paper in the Journal of Monetary Economics that developed a benchmark (at least in our way of thinking) dynamic two-country optimizing macro model of optimal monetary policies in the open economy. Our focus in that paper was deriving optimal policy rules in the two-country model and assessing the gains from international monetary policy cooperation. In that paper, we emphasized the following implications of the model: 
- Optimal monetary policy in each open economy can be written as a Taylor rule, linear in the "domestic" equilibrium real interest rate and the gap between domestic inflation and the inflation target.

- In general, there are gains to international monetary policy cooperation. Optimal monetary policy under cooperation can be written as a Taylor rule in which the domestic as well as the foreign inflation gap enters the reaction function, as well as the equilibrium real interest rate.

- Optimal policy features a flexible exchange rate, and the nominal exchange rate under optimal discretionary policy has a unit root as does the domestic price level, and they are cointegrated. Optimal monetary policy produces a "random walk" nominal exchange rate because under discretion, the central bank cannot credibly commit to a price-level target (but can achieve only a stationary inflation rate).

This paper provides some intuition for these results and develops some further insights into monetary policy in the open economy. The approach I pursue is to "inspect the mechanism" of the two-country Clarida et al. (2002) optimizing model by focusing on the three main building blocks that can be derived from it: the "open-economy" IS curve, the open-economy Phillips curve, and the open-economy Taylor rule. Because these building blocks are derived from a two-country optimizing model, we can use them to gain insight into how special the "special case" of the closed-economy framework is, which does appear to be the starting point for much contemporary monetary policy analysis.

The plan of the paper is as follows. In Section II, I describe the basic structure of the two-country model. In Sections III, IV, and V, I derive and assemble the building blocks of the model: the open-economy IS curve, the open-economy Phillips curve, and the open-economy policy rule. I illustrate and discuss in detail how openness affects the analysis and highlight an interesting empirical implication of the model, namely, that under inflation targeting, bad news about inflation can be good news for the nominal exchange rate, even though in the long run purchasing power parity (PPP) holds so that ultimately bad news about inflation is bad news for the exchange rate. In Section VI, I propose and implement a new approach for calibrating forward-looking Taylor rules that makes use of real-time financial data on inflation-indexed government bonds and break-even inflation in lieu of the instrumental variable/generalized method of moments (GMM) approach introduced in Clarida et al. (1998). I apply this approach to the Fed and European Central Bank (ECB) reaction functions since 2000 and find that it accounts well for Fed policy with much less emphasis on interest rate 
smoothing than in prior work. For the ECB, the results are encouraging but less clear-cut owing to the limited issuance of inflation-indexed bonds during much of the sample. Section VII offers some concluding remarks.

\section{Review of the Theoretical Two-Country Model}

\section{A. Essence of the Model}

The complete model is presented in Clarida et al. (2002) and is sketched out in this section. There are two countries, producing differentiated tradable final goods from a continuum of intermediate labor varieties. Households share identical Cobb-Douglas preferences over a consumption index $C_{t}$ of home and foreign varieties. A key parameter is $\gamma$, which is the share of home spending on foreign goods. The larger $\gamma$ is, the more open the home economy, which is the economy I shall focus on for the purposes of this discussion. The law of one price holds and there is producer currency pricing. Under these assumptions (see Cole and Obstfeld 1991; Corsetti and Pesenti 2001) the complete markets allocation can be achieved through endogenous adjustments in the equilibrium terms of trade, denoted by $S_{t}$, that clear the world goods market.

Household utility takes the standard form

$$
U\left(C_{t}\right)-V\left(N_{t}(h)\right)=\frac{C_{t}^{1-\sigma}}{1-\sigma}-\frac{N_{t}(h)^{1+\phi}}{1+\phi},
$$

where $1 / \sigma$ is the intertemporal elasticity of substitution of consumption, and $N_{t}(h)$ is labor supply. I focus on the benchmark case with $\sigma>1$. However, as I discuss below, this assumption is not innocuous.

Firms produce final output from a variety of intermediate inputs $Y_{t}(f)$ :

$$
Y_{t}=\left[\int_{0}^{1} Y_{t}(f)^{(\xi-1) / \xi} d f\right]^{\xi /(\xi-1)} .
$$

Each intermediate input $Y_{t}(f)=A_{t} N_{t}(f)$ is produced from a variety of labor inputs and an exogenous productivity shock $A_{t}$, where

$$
N_{t}(f)=\left[\frac{1}{1-\gamma} \int_{0}^{1-\gamma} N_{t}(h)^{\eta_{t-1} / \eta_{t}} d h\right]^{\eta_{t} / \eta_{t-1}} .
$$

Note that each household (and each input producer) has market power because labor varieties (and intermediate inputs) are heterogeneous and 
imperfectly substitutable. However, while we assume that money wages are flexible, intermediate goods prices are sticky.

Firms will set prices as a markup over marginal cost. Real marginal cost is just the real product wage scaled by productivity $M C_{t}=$ $(1-\tau)\left(W_{t} / P_{H, t}\right) A_{t}^{-1}$. In our open economy this can be written as

$$
M C_{t}=\frac{(1-\tau)\left(W_{t} / P_{t}\right) S_{t}^{\gamma}}{k A_{t}}
$$

where $P_{t}$ is the consumer price index (CPI), $\tau$ is a wage subsidy, and $k=(1-\gamma)^{(1-\gamma)} \gamma^{\gamma}$. From the first-order condition for labor supply we have

$$
\frac{W_{t}}{P_{t}}=\left(1+\mu_{t}^{w}\right) N_{t}(h)^{\phi} C_{t}^{\sigma},
$$

where $1+\mu_{t}^{w}=\eta_{t} /\left(\eta_{t}-1\right)$ is a wage markup. With flexible wages, all workers are paid the same wage and work the same hours, so the $h$ indicator is redundant and will be suppressed below.

\section{B. Some Equilibrium Conditions}

The following equilibrium conditions hold in both the flexible-price and sticky-price equilibrium. In equilibrium current accounts are in balance period by period, and the consumption index satisfies

$$
C_{t}=k\left(Y_{t}\right)^{1-\gamma}\left(Y_{t}^{*}\right)^{\gamma},
$$

where $Y_{t}^{*}$ is foreign output. The equilibrium terms of trade that brings this about is

$$
S_{t}=\frac{Y_{t}}{Y_{t}^{*}}
$$

In equilibrium, the amount of home output produced will depend on labor supply, productivity, and the dispersion across firms in the prices of intermediate goods:

$$
Y_{t}=\frac{A_{t} N_{t}}{V_{t}}
$$

where $V_{t}$ is an index of price dispersion across intermediate input sellers:

$$
V_{t}=\int\left[P_{h, t}(f) / P_{h, t}\right]^{-\xi} d f .
$$


From all this it follows that equilibrium real marginal cost in the open economy $M C_{t}$ can be written as

$$
M C_{t}=(1-\tau) \kappa^{\sigma-1}\left(1+\mu_{t}^{w}\right) A_{t}^{-(1+\phi)} Y_{t}^{\kappa}\left(Y_{t}^{*}\right)^{\kappa_{0}} V_{t}^{\phi}
$$

where

$$
\kappa=\sigma(1-\gamma)+\gamma+\phi
$$

and

$$
\kappa_{0}=\sigma \gamma-\gamma
$$

Marginal cost spillovers. The sign of the effect of foreign output on home marginal cost is given by $\kappa_{0}$. Under our assumption that $\sigma>1, \kappa_{0}$ is positive and, thus, so is the spillover from foreign output to domestic marginal cost. A rise in foreign output improves the home terms of trade, and this, by increasing the purchasing power of home wages, will tend to lower home marginal cost with an elasticity of $\gamma$. But the improvement in the home terms of trade will also raise the consumption index and lower the marginal utility of work, and thus raise marginal cost with an elasticity of $\gamma \sigma$. In the benchmark case $\sigma>1$, this income effect from a foreign output expansion dominates the substitution effect and marginal cost spillovers are positive. However, if $\sigma<1$, the substitution effect dominates and a rise in foreign output lowers home marginal cost. In the knife-edge case $\sigma=1$, there are no international spillovers to home marginal cost.

Although our focus will be on the sticky-price equilibrium, it is useful to solve for the flexible-price equilibrium, the case in which all firms can change their price every period. In this case, $P_{H, t}$ will be common across firms and will be a constant markup over nominal marginal cost, so that real marginal cost will be constant and equal to $\overline{M C}=1 /\left(1+\mu^{p}\right)$, where an overbar represents the flexible-price equilibrium and $1+\mu^{p}=$ $\xi /(\xi-1)$. Every firm will choose the same price, so $V_{t}=1$ and we have

$$
\bar{Y}_{t}=A_{t} \bar{N}_{t}
$$

Using (9), which always holds, and the expression for real marginal cost, which holds under flexible prices, we can solve for the "natural" level of home output consistent with a given level of foreign output and the mean level of the wage markup:

$$
\bar{Y}_{t}=\left[\frac{\kappa^{1-\sigma} A_{t}^{1+\phi}\left(Y_{t}^{*}\right)^{-\kappa_{0}}}{(1-t)\left(1+\mu^{w}\right)\left(1+\mu^{p}\right)}\right]^{1 / \kappa}
$$


Thus in the open economy the natural rate of output is a function of foreign output unless $\sigma=1$. When $\sigma>1$, a rise in foreign output, with home productivity held constant, raises home marginal cost, and this lowers home natural output because the income effect from the terms of trade gain lowers the flexible-price labor supply. Moreover, this effect is larger the more open the economy. Note, however, that if the source of the rise in foreign output is a productivity shock that is positively correlated with home productivity, the reduced-form correlation between home natural output and foreign output can be positive even for the case $\sigma>1$.

\section{The Open-Economy IS Curve}

In this model, as in many other new open-economy macro models, the path for optimal consumption must satisfy an Euler equation of the form

$$
c_{t}=E\left\{c_{t+1}\right\}-\frac{1}{\sigma}\left(r_{t}-E_{t}\left\{\pi_{t+1}\right\}-\gamma E_{t}\left\{\Delta s_{t+1}\right\}\right),
$$

where $r_{t}$ is the nominal interest rate, $\pi_{t}$ is domestic inflation, and lowercase letters for all other variables denote log deviations from the nonstochastic steady state. We note that $\pi_{t+1}^{\mathrm{CPI}}=\pi_{t+1}+\gamma \Delta s_{t+1}$. How do we turn this into an open-economy IS curve? We start by recognizing that with balanced trade $y_{t}=c_{t}+\gamma s_{t}$ and substitute out for $c_{t}$ and $c_{t+1}$. We obtain an Euler equation in $y_{t}$ :

$$
y_{t}=E_{t} y_{t+1}+\gamma s_{t}-\gamma E_{t} s_{t+1}-\sigma^{-1}\left(r_{t}-E_{t}\left\{\pi_{t+1}\right\}-\gamma E_{t}\left\{\Delta s_{t+1}\right\}\right) .
$$

The terms of trade plays several roles. As in static models, a terms of trade worsening boosts exports and increases demand for domestic output. But an anticipated terms of trade worsening raises expected inflation and lowers the consumption real interest rate for any given nominal interest rate. Consider the special case in which $E_{t} y_{t+1}=\rho y_{t}$ and $E_{t} s_{t+1}=\rho s_{t}$ (which in fact will be the case under optimal monetary policy with an exogenous home cost push shock, no foreign cost push shock, and constant productivity as shown in Clarida et al. [2002]). In this case the open-economy IS curve can be written as

$$
y_{t}=\gamma\left(1-\sigma^{-1}\right) s_{t}-[(1-\rho) \sigma]^{-1}\left(r_{t}-E_{t} \pi_{t+1}\right) .
$$

This is form of the IS curve often found in traditional overshooting literature. We note that with the benchmark case $\sigma>1$, a rise in $s_{t}$ that increases the relative price of foreign goods in terms of home goods will 
boost aggregate demand for home output. Of course, a rise in the real interest rate reduces aggregate demand for home output.

In this particular model, we have more structure, so we can say more about the open-economy IS curve. We know that $s_{t}=y_{t}-y_{t}^{*}$. So we can substitute out for $s_{t}$. Defining the log domestic output gap $\tilde{y}_{t}=y_{t}-\bar{y}_{t}$, we obtain

$$
\tilde{y}_{t}=E_{t}\left\{\tilde{y}_{t+1}\right\}-\sigma_{0}^{-1}\left(r_{t}-E_{t}\left\{\pi_{t+1}\right\}-\overline{r r}_{t}\right)
$$

where

$$
\overline{r r}_{t}=\sigma_{0} E_{t}\left\{\Delta \bar{y}_{t+1}\right\}+\kappa_{0} E_{t}\left\{\Delta y_{t+1}^{*}\right\}
$$

is the domestic natural real interest rate, with

$$
\sigma_{0}=\sigma-\gamma(\sigma-1)
$$

where it will be recalled that $\kappa_{0}=\gamma(\sigma-1)$. In our benchmark case, $\sigma>1$ and $\kappa_{0}>0$. Also note for the benchmark case that $\sigma_{0}$ is decreasing in $\gamma$, the parameter that indexes openness.

There is a lot going on here, so let us take stock. We have derived an open-economy IS curve in terms of the domestic output gap and the gap between the domestic real interest rate and the appropriate natural real interest rate. How is this an open-economy IS curve? First, as discussed above, the natural rate of output in the open economy depends on the level of foreign output,

$$
\bar{Y}_{t}=\left[\frac{\kappa^{1-\sigma} A_{t}^{1+\phi}\left(Y_{t}^{*}\right)^{-\kappa_{0}}}{(1-t)\left(1+\mu^{w}\right)\left(1+\mu^{p}\right)}\right]^{1 / \kappa},
$$

and thus the domestic output gap does depend on foreign output.

Second, the slope of the open-economy IS curve depends on how open the economy is. In our benchmark case $\sigma>1$, the semielasticity of aggregate demand for domestic output with respect to the real interest rate is increasing in openness. In other words, in our benchmark case, a more open economy has a flatter IS curve, so that the central bank gets more bang out of every basis point buck by which it changes the policy rate.

Third, the appropriate natural or neutral real interest rate depends on foreign output growth as well as home output growth:

$$
\overline{r r}_{t}=\sigma_{0} E_{t}\left\{\Delta \bar{y}_{t+1}\right\}+\kappa_{0} E_{t}\left\{\Delta y_{t+1}^{*}\right\} \text {. }
$$

In the special case $\sigma=1$, this reduces to the standard growth model in which the neutral real interest rate is equal to the domestic growth rate in potential output. In the benchmark case with $\sigma>1, \kappa_{0}$ is positive, and 
the neutral domestic real interest rate is positively correlated with foreign growth. Moreover, the more open the economy, the more important the effect of foreign output growth on the domestic real interest rate.

\section{The Open-Economy Phillips Curve}

We assume as in Calvo that prices of domestic intermediate goods are sticky and that a constant fraction $1-N$ of firms can change price every period. The optimal price chosen at date $t$ is given by

$$
E_{t} \sum_{j=0}^{\infty} N^{j} Q_{t, t+j} Y_{t}(f)\left[P_{H, t}^{0}-\left(1+\mu^{p}\right) P_{H, t+j} M C_{t+j}\right]=0,
$$

where $Q_{t, t+j}$ is the standard stochastic discount factor. With this standard staggered price model, the domestic price index evolves according to

$$
P_{H, t}=\left[N\left(P_{H, t-1}\right)+(1-N)\left(P_{H, t}^{0}\right)\right]^{1 /(1-\xi)} .
$$

From this it follows that domestic inflation (producer price index [PPI] inflation) evolves according to

$$
\pi_{t}=\delta m c_{t}+\beta E_{t}\left\{\pi_{t+1}\right\}
$$

where $\delta=(1-N)(1-\beta N) / N$.

Thus domestic inflation in the open economy is driven by the present value of log real marginal cost. But what is log real marginal cost in the open economy? One way to express log real marginal cost is simply

$$
m c_{t}=\mu_{t}^{w}+\phi n_{t}+\sigma c_{t}+\gamma s_{t}-a_{t} .
$$

As is evident from this equation, other things equal, an improvement in the home terms of trade, a fall in $s_{t}$, lowers real marginal cost and is thus disinflationary. Moreover, the more open the economy, the larger the effect of the terms of trade on real marginal cost and thus on inflation.

Given the structure of our model, it is possible to express real marginal cost as a function of home output, foreign output, and productivity:

$$
m c_{t}=\mu_{t}^{w}+\kappa y_{t}+\kappa_{0} y_{t}^{*}-(1+\phi) a_{t} .
$$

However, from the definition of domestic natural output, we know that $\bar{y}_{t}=\kappa^{-1}\left[(1+\phi) a_{t}-\kappa_{0} y_{t}^{*}\right]$. It follows that in equilibrium, the log of real marginal cost can be written as

$$
m c_{t}=\kappa \tilde{y}_{t}+\mu_{t}^{w},
$$

where it will be recalled that $\kappa=\sigma(1-\gamma)+\gamma+\phi$. 
The open-economy Phillips curve follows immediately:

$$
\pi_{t}=\beta E_{t}\left\{\pi_{t+1}\right\}+[\sigma(1-\gamma)+\gamma+\phi] \delta \tilde{y}_{t}+u_{t},
$$

where $\lambda=\delta \kappa$. We see that, in our benchmark case with $\sigma>1$, the more open economy has a flatter Phillips curve in terms of domestic (PPI) inflation. ${ }^{1}$ The intuition is as follows. The more open the economy, the smaller the impact of a change in domestic output on the domestic consumption index and thus the marginal utility of consumption, so this tends to reduce the impact of domestic output on marginal cost. However, the more open the economy, the greater the impact on marginal cost of the terms of trade change that follows from a change in output. In our benchmark case, the income effect of the rise in output outweighs the induced effect of the terms of trade change, resulting in a flatter openeconomy Phillips curve. In practice, many central banks target CPI, not PPI, inflation. The Phillips curve expressed in terms of CPI inflation will contain an additional term $\gamma \Delta e$ reflecting the assumed full pass-though of the exchange rate to import prices. The impact of a shock on a CPI openeconomy Phillips curve will depend on the nature of the shock, for example, a productivity shock as opposed to a cost push shock, as well as $\sigma$. Potentially also, the slope of the CPI Phillips curve will depend on the credibility of the inflation target (which in this paper is assumed credible) as well as on the policy rule (e.g., to the extent that money growth or interest rates lean against the exchange rate).

\section{Completing the Model: Policy Rules for the Open Economy}

Combining our IS and Phillips curve and terms of trade equations, we have

$$
\begin{aligned}
\tilde{y}_{t} & =E_{t}\left\{\tilde{y}_{t+1}\right\}-\sigma_{0}^{-1}\left(r_{t}-E_{t}\left\{\pi_{t+1}\right\}-\overline{r r}_{t}\right), \\
\pi_{t} & =\beta E_{t}\left\{\pi_{t+1}\right\}+\lambda \tilde{y}_{t}+u_{t}, \\
s_{t} & =\left(\tilde{y}_{t}-\tilde{y}_{t}^{*}\right)+\left(\bar{y}_{t}-\bar{y}_{t}^{*}\right),
\end{aligned}
$$

where the home country takes foreign output as given. To close the model, we need to specify a path for the home nominal interest rate.

As is customary in this literature, we assume that the central bank maximizes

$$
W^{H}=-(1-\gamma) \frac{\Lambda}{2} E_{0} \sum_{t=0}^{\infty} \beta^{t}\left(\pi_{t}^{2}+\alpha \tilde{y}_{t}^{2}\right) .
$$


Clarida et al. (2002) show that this quadratic approximation to the social welfare function in the open economy can be derived as in Woodford (2003) and that at a social optimum $\alpha=\lambda / \xi$ or

$$
\alpha=\frac{[\sigma(1-\gamma)+\gamma+\phi] \delta}{\xi} .
$$

Thus, in our benchmark case, we see that a more open economy places a smaller weight on output stabilization and thus a larger weight on inflation stabilization. This follows directly from the fact that the more open economy has a flatter Phillips curve under our benchmark case.

Under discretion, optimal policy must satisfy the following first-order conditions:

$$
\begin{gathered}
\tilde{y}_{t}=-\frac{\lambda}{\alpha} \pi_{t}, \\
\pi_{t}=\Psi u_{t},
\end{gathered}
$$

with $\Psi=[(1-\beta \rho)+\lambda \xi]^{-1}$, where $\rho$ is the exogenous autocorrelation in shocks to the markup. ${ }^{2}$ One way to write the optimal monetary policy in the open economy is as a forward-looking Taylor rule,

$$
r_{t}=\overline{r r}_{t}+\theta E_{t}\left\{\pi_{t+1}\right\},
$$

with

$$
\theta=1+\frac{\xi \sigma_{0}(1-\rho)}{\rho}>1 .
$$

We see immediately that for our benchmark case with $\sigma_{0}$ decreasing in $\gamma$, in a more open economy the central bank needs to lean less against the wind for any given inflation shock. This is so even though the more open economy places a greater weight on inflation stabilization. The intuition for this result is that for our benchmark case of $\sigma>1$, the more open economy has a flatter IS curve, which means that the central bank gets more bang out of every basis point:

$$
y_{t}=\gamma\left(1-\sigma^{-1}\right) s_{t}-[(1-\rho) \sigma]^{-1}\left(r_{t}-E_{t} \pi_{t+1}\right) .
$$

In effect, a given rise in the real interest rate affects aggregate demand through two channels, exports and domestic consumption. Under a Taylor rule, an inflation shock is met by a rise in the ex ante real policy rate, and this induces a real appreciation and an improvement in the terms of trade.

While there is a unique way to write the optimal policy rule as a function of the model's state variables $\left\{a_{t}, a_{t}^{*}, u_{t}, u_{t}^{*}\right\}$, there are several 
ways to express the policy rule in terms of endogenous variables so that (30) is by no means unique. For example, we can also write the optimal policy rule as

$$
r_{t}=\overline{r r}_{t}+(\theta-1) E_{t} \pi_{t+1}+\rho\left[\Delta e_{t}-\left(\Delta y_{t}-\Delta y_{t}^{*}\right)\right],
$$

where we assume for expositional convenience that $\pi^{*}=0$. Thus, while in our open-economy framework it is possible to write the optimal policy rule without explicitly including the nominal exchange rate, there is an equivalent way to express the rule that includes the nominal exchange rate of depreciation as well as the growth rate differential between the home and foreign country. The intuition is as follows. A nominal rate of depreciation equal to the growth differential will produce a terms of trade adjustment that clears the global goods market without any change in domestic prices. If the rate of depreciation exceeds the growth differential, that means there is positive domestic inflation and the central bank should lean against it. Just for completeness, we note that it is possible to write the optimal policy rule without including domestic inflation at all:

$$
r_{t}=\overline{r r}_{t}+\theta \rho\left[\Delta e_{t}-\left(\Delta y_{t}-\Delta y_{t}^{*}\right)\right]
$$

where the coefficient $\theta \rho$ satisfies the Taylor principle for our benchmark case of $\sigma>1$.

A key empirical implication of the above analysis is that under optimal monetary policy, bad news about inflation can be good news for the exchange rate, even if long-run PPP requires that bad news about inflation is bad news for the exchange rate. That is, when there is a shock that pushes inflation up, the nominal exchange rate under optimal monetary policy appreciates on impact, even though with PPP holding in the long run, and with a unit root in the price level, the exchange rate must depreciate. The reason is that the inflation shock induces the central bank to raise the real interest rate today and in the future, and the expected path of higher than steady-state real interest rates can be sufficient to trigger a nominal appreciation. This is easiest to see in the borderline case of $\sigma=1$ and constant productivity. We then have $s_{t}=-\left[(\theta-1) \rho \pi_{t}\right] /(1-\rho)$. Bad news about inflation will be good news for the exchange rate if and only if $(\theta-1) \rho /(1-\rho)>1$. Thus, for an arbitrary, but stable, Taylor rule coefficient $\theta>1$, if shocks to inflation are sufficiently persistent, bad news about inflation will be good news for the exchange rate. However, under optimal policy, from (31) we have

$$
s_{t}=-\xi \sigma_{0} \pi_{t}
$$


Table 1

Regression of Exchange Rate Change on Inflation Surprise in 10-Minute Window before and after Announcement: Bad News Is Good News for the Exchange Rate for Inflation Targeter Countries

\begin{tabular}{lccccc}
\hline & \multicolumn{2}{c}{ Headline } & & \multicolumn{2}{c}{ Core } \\
\cline { 2 - 3 } \cline { 5 - 6 } & $\begin{array}{c}\text { Month over } \\
\text { Month }\end{array}$ & $\begin{array}{c}\text { Year over } \\
\text { Year }\end{array}$ & & $\begin{array}{c}\text { Month over } \\
\text { Month }\end{array}$ & $\begin{array}{c}\text { Year over } \\
\text { Year }\end{array}$ \\
\hline Coefficient & .2 & .2 & .5 & .5 \\
$t$-statistic & 5.9 & 6.2 & & 9.7 & 9.2 \\
$R^{2}$ & .08 & .09 & & .27 & .25 \\
Observations & 394 & 387 & & 257 & 259 \\
\hline
\end{tabular}

Source: Working paper version of Clarida and Waldman (2008), table 3.

Note: Regression method: stacked ordinary least squares. Percentage change in exchange resulting from a 1-percentage-point upward surprise in inflation. A positive coefficient indicates appreciation of domestic currency. The countries included are Australia, Canada, the euro area, Japan, New Zealand, Norway, Sweden, Switzerland, the United Kingdom, and the United States. Data are for July 2001 to December 2005. Some countries are missing observations.

with $\xi \sigma_{0}>1$ so that bad news about inflation is good news for the exchange rate under optimal policy. Clarida and Waldman (2008) generalize this result to allow for endogenous inflation persistence. In their model, the greater $\theta$ is, the less persistent inflation is (and the deviations from PPP caused by Phillips curve shocks). They show empirically in an event study (please see table 1) that for inflation targeting countries, bad news about inflation is indeed good news for the exchange rate in that announcements of higher (lower) than expected inflation on the date inflation statistics are released are significantly correlated with appreciations (depreciations) of the exchange rate after the announcement. ${ }^{3}$

\section{A Real-Time Forward-Looking Taylor Rule for the Fed and the ECB}

\section{A. Background and Motivation}

It is standard now to estimate forward-looking Taylor rules of the form

$$
r_{t}=\overline{r r}_{t}+\theta E_{t}\left\{\pi_{t+n}\right\}+f E_{t}\left\{\tilde{y}_{t+m}\right\}
$$

using an instrumental variable/GMM approach (Clarida et al. 1998, 1999). ${ }^{4}$ We observe that while our theoretical model suggests circumstances under which the optimal monetary policy rule for the open economy can be expressed in "inflation nutter" form without an output gap term, many central banks appear to conduct (or, in the case of the Bundesbank, did in the past conduct) policy with an implicit dual mandate. 
Of course the world's leading central bank-the Fed-has an explicit dual mandate. The approach introduced in Clarida et al. (1998) uses first-stage regressions of inflation and the output gap on a set of macro instruments to estimate the forward-looking Taylor rule and test the cross-equation restrictions implied by the theory. Often in this work, it is assumed, following Taylor, that the "neutral" real interest rate is constant.

In this section, I would like to suggest an alternative approach for calibrating a forward-looking Taylor rule that makes use of recently available real-time financial data on real interest rates on inflationindexed bonds and break-even inflation-the difference between the yield on a nominal bond and an inflation-indexed bond. A potential advantage of this approach is that it may be robust to specification error arising from equating first-stage regressions of inflation on a set of macro instruments with evolving central bank expectations of inflation. In particular, it is potentially robust to regime changes, learning, and structural shifts that have affected expectations about future real interest rates and inflation. It is also an intuitive way to allow for a timevarying real interest rate. Subject to data availability, I do this by using variation in forward real interest rates relative to a constant risk/term premium as an indicator of where the financial markets think real rates will settle down after business cycle influences dissipate. For the United States, I use 5-year forward real interest rates computed from the yields on Treasury Inflation-Protected Securities (TIPS) with 10 years and 5 years to maturity to extract these forward rates. For the European Monetary Union (EMU), data limitations preclude our extracting a full time series for our entire study of forward inflation-indexed interest rates, so we must use instead the yield on the first inflation-indexed bond for an EMU country (issued by France in 1998) that matures in 2009. As the purpose here is calibration, not econometrics, we will follow Taylor's original approach and use "eyeball" regression to assess the match between a real-time Taylor rule and Fed and ECB policy since 2000. ${ }^{5}$

The approach of this paper is straightforward. Instead of projecting realized inflation on a set of macro instruments to proxy for expected inflation, I use the financial market determined break-even inflation. Break-even inflation is just the difference between the nominal yield on a government bond and the yield on an inflation-indexed bond. I allow for a constant risk premium to compensate risk-averse investors for the inflation risk they take on with a nominal government bond. I also allow for time variation in the "neutral" real interest rate. Instead of building a macro model for the neutral U.S. real interest rate, I extract from the TIPS yield curve a forward real interest rate. I select the 5-year 
TIPS yield 5 years forward for two reasons. First, a consistent data series on 5-year TIPS yields 5 years forward is available from Bloomberg going back to 2000 . Second, the business cycle/monetary policy influences on short-term real interest rates can plausibly be expected to have died out after 5 years, at least in expectation. As with break-even inflation, I allow for a constant term premium in the TIPS yield curve to account for a positive slope between the unobserved expected real policy rate 5 years forward and the 5 -year forward TIPS yield. When investors price the real yields on 5-year and 10-year TIPS, they are also pricing 5-year TIPS 5 years forward. Under the restriction of a constant real term premium, variation in this real yield 5 years forward can provide information about where the markets think real yields will be after near-term business cycle and monetary policy impacts have dissipated (which they presumably will, at least in expectation, after 5 years). Finally, for the output gap measure I use an unemployment gap with an Okun's law coefficient of 2.5 and a natural rate of 4.75 , which is consistent with the Fed's recent medium-term forecasts (cf. Clarida et al. 1999). Thus the output gap equals

$$
\tilde{y}_{t}=2.5\left(4.75-u_{t}\right),
$$

with $u_{t}$ equal to a measure of the unemployment rate (either actual or forecast). I use both contemporaneous unemployment and surveys of expected future unemployment rates to calibrate our Fed reaction function. The approach for the ECB is similar, with the caveats discussed above due to data availability. I use the inflation-indexed real rate on the French inflation linked bond maturing in 2009 (and issued in 1999) as the measure of the real ECB rate and the difference between that real rate and the yield on the matching nominal French government bond (also maturing in 2009) as the measure of break-even inflation. For the output gap measure for EMU, I also use an unemployment gap with an Okun's law coefficient of 2.5 but with a natural rate of 8 , which is consistent with the empirical estimates for Okun coefficients for EMU countries reported in Sogner and Stiassny (2000). Thus, for EMU the output gap equals

$$
\tilde{y}_{t}^{\mathrm{EMU}}=2.5\left(8-u_{t}^{\mathrm{EMU}}\right) \text {. }
$$

\section{B. Results for the Fed}

To establish some perspective, in figure 1, I plot the path of the federal funds rate since 2000 against the original, backward-looking Taylor rule 

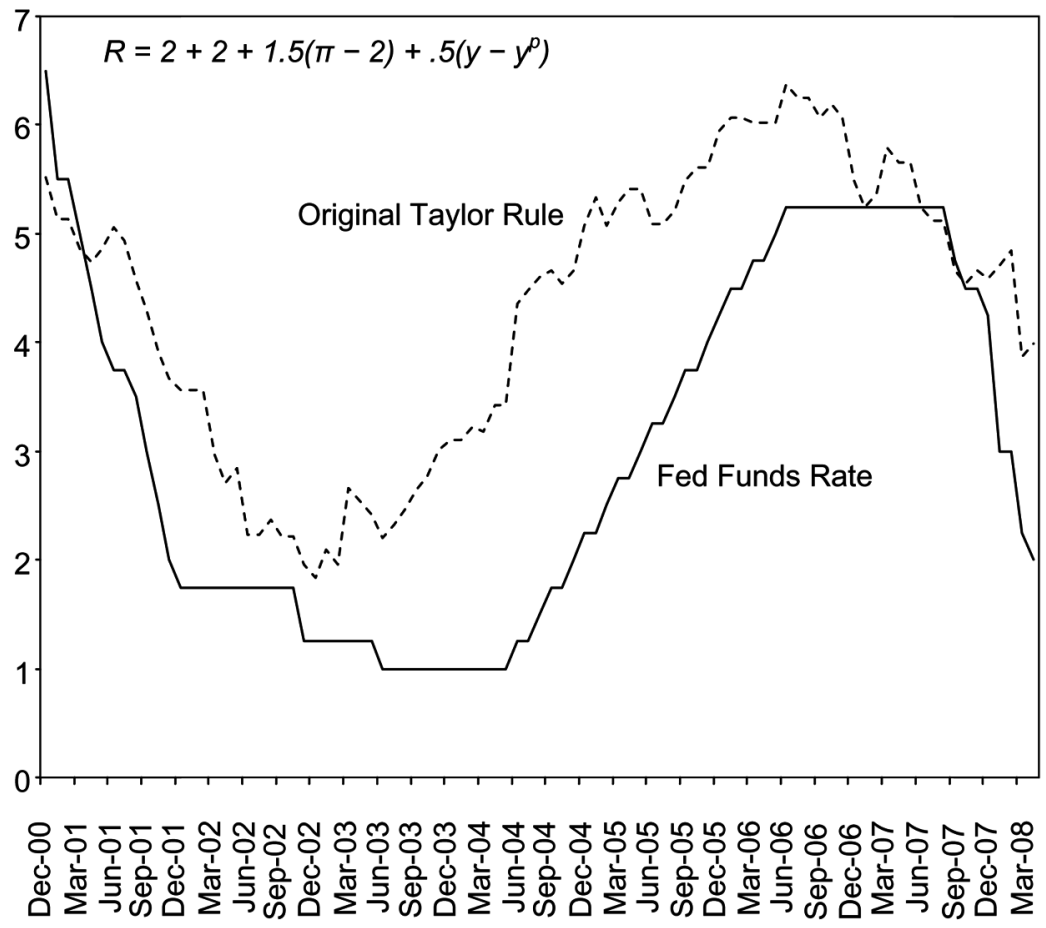

Fig. 1. Original Taylor rule does not describe the Bernanke/Greenspan Fed since 2000

(with the four-quarter change in the GDP deflator) with Taylor's assumptions of a constant neutral real interest rate and with his original parameters of $\theta=1.5$ and $f=0.5$. In figure 2, I next plot a real-time forward-looking Taylor rule using the 5-year forward 5-year real interest rate from the U.S. TIPS curve as a proxy for the neutral real interest rate and using break-even inflation over 5 years as a proxy for expected inflation (and assuming an implicit inflation target of $2 \%$ ).

So a real-time forward-looking Taylor rule with Taylor's weights does not describe the Greenspan/Bernanke Fed during this decade. But there is nothing special about Taylor's weights. They reflect his preferences. In general, stability requires only that the parameter on inflation $\theta$ exceed one (Woodford 2003, 2007). I suspect the reason is that the Greenspan/Bernanke Fed places more weight on output stabilization than a Taylor Fed would. That is, they have taken the dual mandate seriously. Here is the realtime Taylor rule with double John Taylor's weight on the output gap.

As can be seen from figure $3 a$, the real-time forward-looking Taylor rule does a reasonable job of describing the Greenspan/Bernanke Fed 


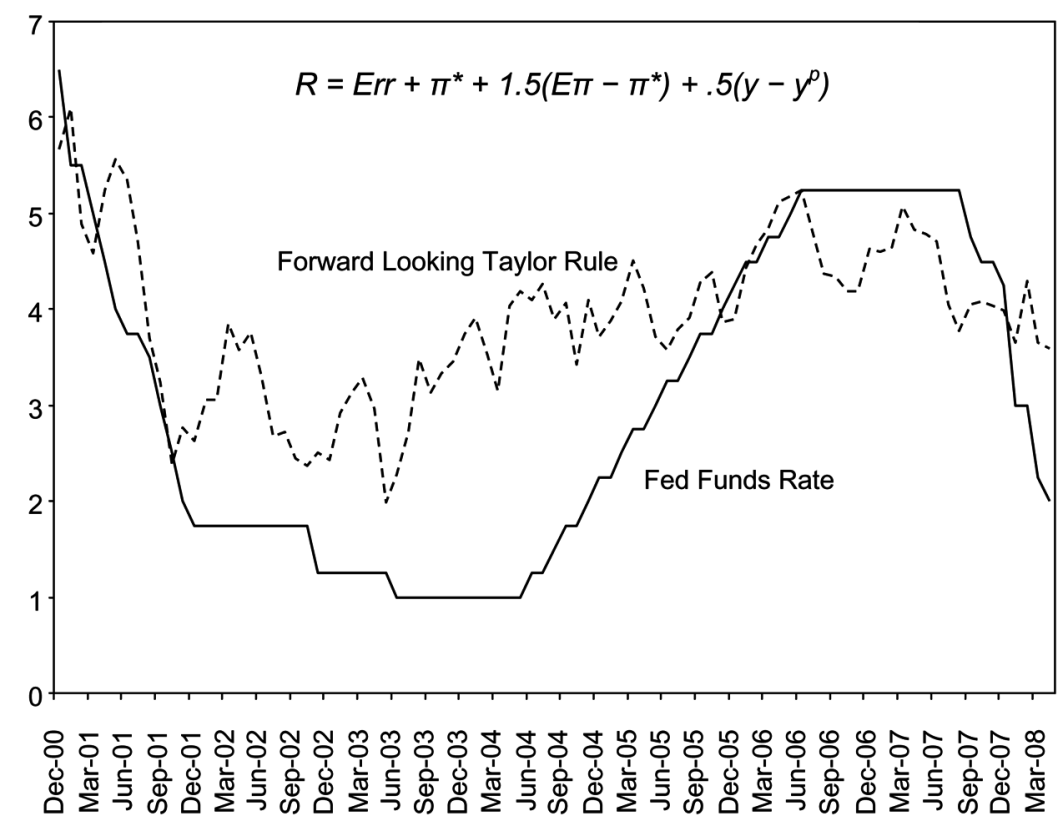

Fig. 2. A real-time forward-looking Taylor rule with Taylor weights

during this decade. Note that this calibration of the forward-looking Taylor rule does not incorporate interest rate smoothing. The half-life of deviations of the funds rate from the forward-looking Taylor rule is quite short, only 3 months. ${ }^{6}$ One episode in which policy deviates for some time from this rule appears to be June 2003-November 2005. Also, more recently in 2008, policy appears to be easier than this rule would imply. However, up till now, we have used the actual unemployment rate to back out output gap. But a fully forward-looking Taylor rule should also use a forecast of where unemployment is going, not what it is today. To focus on the recent Fed decisions, figure $3 b$ shows the evolving consensus forecast of 2008:Q4 unemployment replacing actual unemployment.

As can be seen from the figure, the Fed has been easing right on its Taylor rule path-with double weight on output gap-using publicly available, rolling forecasts of future unemployment for 2008:Q4 starting in January 2008. That is, Bernanke is following the path of ease in 2007-8 that Greenspan did in 2001-2. The Bloomberg survey of economists as of May 2008 is for an unemployment rate of 5.5\% in 2008:Q4. That is consistent with Fed funds at 2, which is where it is as of this writing. Even though expected inflation is higher than desired, unemployment rising to $5.5 \%$ in tandem with a fall in the neutral real rate can account 
a

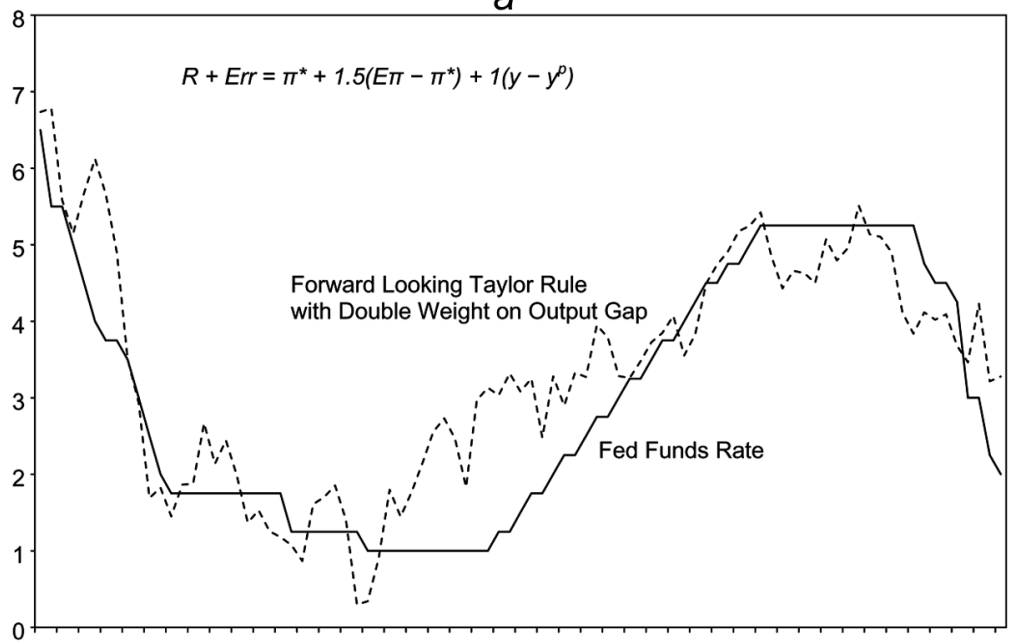

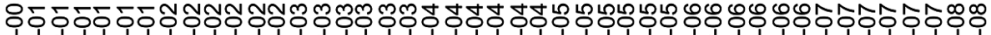

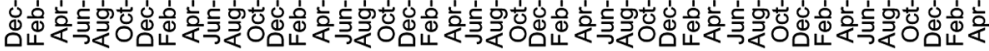

b

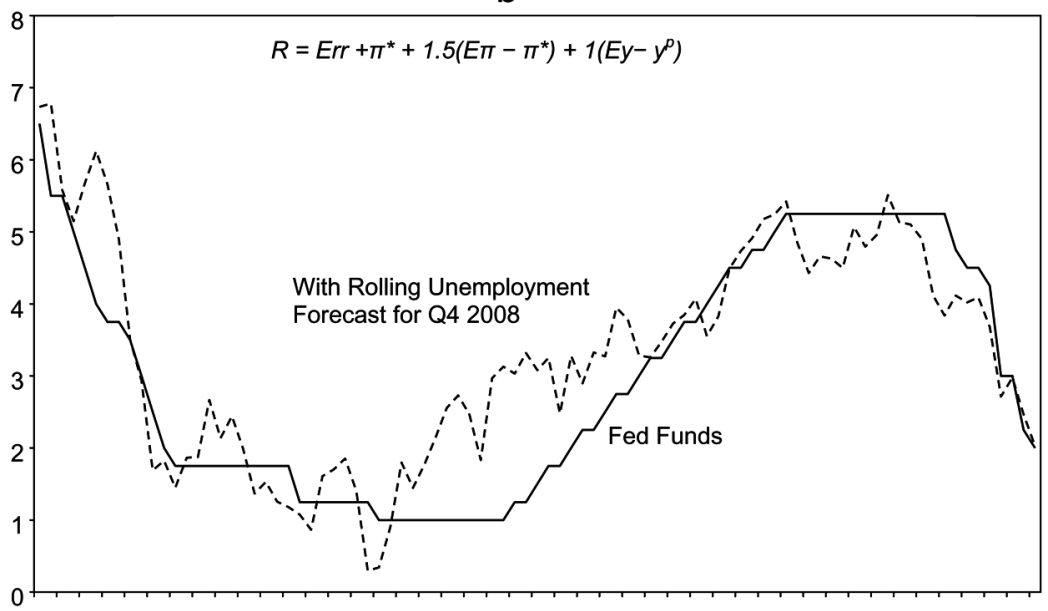

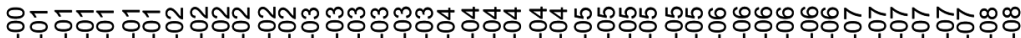

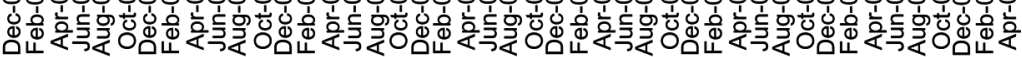

Fig. 3. Real-time Taylor rule with double weight on output gap. $a$, Taking the dual mandate seriously. $b$, Rolling Bloomberg forecast of 2008:Q4 unemployment rate (starts in January 2008). 
for Fed policy so far in this cycle. Bernanke himself has attributed the fall in real interest rates to a "global saving glut" (Bernanke 2005). This indicates that the Fed takes seriously the global influence on U.S. neutral real interest rates. Greenspan during his tenure alluded to the "conundrum," a situation in which the Fed's influence over long-term interest rates is much diminished compared to previous periods, a phenomenon that has been attributed to the globalization of the financial markets in a world of (explicit or implicit) inflation targeting (Greenspan 2007). According to this analysis, variations in the neutral real interest rate, perhaps due to the global saving glut and enhanced financial integration in a world of inflation targeting central banks, have played an important role in Fed policy this decade.

\section{Results for the ECB}

Figure 4 shows the ECB policy rate versus the forward-looking Taylor rule (with the proxies for expected inflation and the real interest rate discussed in Sec. VI.A). For weights, I use the estimated weights for the old estimated Bundesbank policy rule, $\theta=1.3$ and $f=0.25$, presented at ISOM 10 years ago and published in Clarida et al. (1998). Results with Taylor weights are similar, but my eyeball prefers these.

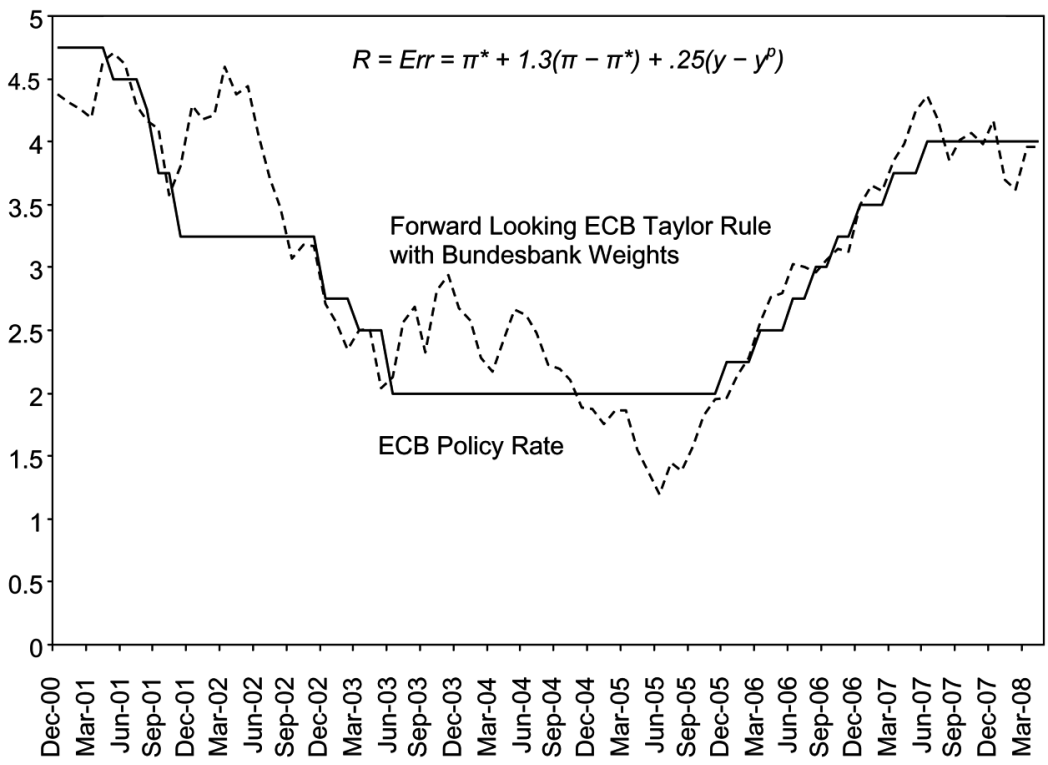

Fig. 4. Real-time Taylor rule for ECB using Bundesbank weights from Clarida et al. (1998) 
As is the case for the Fed calibration, this calibration for the ECB does not incorporate interest rate smoothing. Interestingly, the estimated half-life of deviations of the ECB policy rate from the forward-looking Taylor rule is almost identical to that estimated for the Fed, approximately 3 months. As discussed above, owing to the lack of a more complete term structure of inflation-indexed rates in the EMU, the proxies for expected inflation and the neutral real interest rate are less than ideal. Since 2004, a more extensive issuance of inflation-indexed bonds in the EMU with a range of maturities is beginning to make available a term structure of real yields that can be used to calculate true forward real interest rates (and shorter-term break-even inflations). Nonetheless, even with the data available now, figure 4 illustrates the potential value of our approach for calibrating and interpreting ECB central bank policy actions.

\section{Concluding Remarks}

I have shown that an explicit, two-country optimizing framework yields a number of specific predictions with regard to the effect of openness on monetary policy. I would argue that policy makers ignore openeconomy influences at their peril. I would emphasize that the main points presented in this paper are robust to the illustrative model reviewed here and in particular that such key inputs to monetary policy as the neutral real interest rate and potential output cannot be defined, modeled, or proxied without reference to an explicit global framework. Moreover, empirical evidence cited in the paper appears to support the prediction of the model that increased globalization is making flatter the slope of the Phillips curve, a key input to any sensible monetary policy calculus. ${ }^{7}$ Finally, in Section VI, I introduced a new and, to me, informative way to calibrate policy rules in real time using data from the inflation-indexed bond markets to recover proxies for expected inflation and the neutral real interest rate.

\section{Endnotes}

1. Please see the recent survey by the Bank for International Settlements (Borio and Filardo 2007) for evidence that Phillips curves have become flatter in recent years.

2 . This is true for any $\alpha$. Under optimal policy, $\alpha$ is pinned down as discussed in the text and is equal to $\xi$.

3. For an intuitive, textbook discussion of the Clarida-Waldman result, see Krugman and Obstfeld (2007, 541-43). See also Engel, Mark, and West (2008).

4. The approach was first presented at ISOM 1997, published as Clarida et al. (1998). 
5. Inflation-indexed securities were introduced in the United States only in mid-1997 and in Europe in mid-1998; they were thinly traded for the first couple of years of their existence. The market-clearing default-free and fully inflation-indexed real rates on TIPS were very high —as high as $4.5 \%$ - suggesting that in these early years TIPS yields had to compensate investors for the product's novelty and lack of a deep and liquid market by offering a higher than real return than could be expected on nominal Treasuries of the same maturity (Sack 2007). To allow some time for the market for TIPS and French inflationlinked bonds to become established, I focus on the Fed and ECB rate cycles beginning in 2000.

6. That is, a regression of the residual on the lagged residual yields a coefficient of 0.80 on monthly data. The point estimate is almost identical for the ECB calibration.

7. This model is one way to see these and other global influences on monetary policy in a clear way. Of course, there are other, perhaps more realistic, but complex, models with a richer set of global interactions (Coenen et al. 2007; Erceg, Gust, and Salido 2007) that confirm the importance of global influences on domestic monetary policy.

\section{References}

Bernanke, B. 2005. "The Global Saving Glut and the US Current Account Deficit." Sandridge Lecture, Virginia Association of Economics, Richmond, April.

Borio, C., and A. Filardo. 2007. "Globalisation and Inflation." Working Paper no. 227 (May), Bank for International Settlements, Basel, Switzerland.

Clarida, Richard, Jordi Gali, and Mark Gertler. 1998. "Monetary Policy Rules in Practice: Some International Evidence." European Economic Review 42:1033-67.

$\rightarrow-1999$. "The Science of Monetary Policy." Journal of Economic Literature 37 (December): 1661-1707.

$\rightarrow \longrightarrow$. 2002. "A Simple Framework for International Monetary Policy Analysis." Journal of Monetary Economics 49:879-904.

Clarida, Richard, and Daniel Waldman. 2008. "Is Bad News about Inflation Good News for the Exchange Rate?" In Asset Prices and Monetary Policy, ed. John Campbell. Chicago: University of Chicago Press (for NBER).

Coenen, G., G. Lombardo, F. Smets, and R. Straub. 2007. "International Transmission and Monetary Policy Cooperation." Paper presented at the NBER Conference on International Dimensions of Monetary Policy, Catalonia, Spain, June 11-13.

Cole, Harold L., and Maurice Obstfeld. 1991. "Commodity Trade and International Risk Sharing: How Much Do Financial Markets Matter?" Journal of Monetary Economics 28:3-24.

$\rightarrow$ Corsetti, Giancarlo, and Paolo Pesenti. 2001. "Welfare and Macroeconomic Independence." Quarterly Journal of Economics 116 (May): 421-45.

Engel, C., N. Mark, and K. West. 2008. "Exchange Models Are Not as Bad as You Think?" NBER Macroeconomics Annual 2007:381-441.

Erceg, C., C. Gust, and D. L. Salido. 2007. "The Transmission of Domestic Shocks in Open Economies." Paper presented at the NBER Conference on International Dimensions of Monetary Policy, Catalonia, Spain, June 11-13.

Greenspan, A. 2007. The Age of Turbulence: Adventures in a New World. New York: Penguin.

Krugman, Paul, and Maurice Obstfeld. 2007. International Economics. 8th ed. Boston: Addison-Wesley.

Sack, B. 2007. "Are Long Term Real Yields Now Attractive?" Macreconomic Advisers Report, June.

Sogner, L., and A. Stiassny. 2000. "A Cross Country Study of Okun's Law." Working Paper no. 13, Vienna University of Economics. 
Woodford, Michael. 2003. Interest and Prices: Foundations of a Theory of Monetary Policy. Princeton, NJ: Princeton University Press.

___ 2007. "Globalization and Monetary Control." Manuscript (July), Columbia University. 